\title{
It's Complicated: The Challenge of Prosecuting TNCs for Criminal Activity Under International Law
}

Jena Martin

West Virginia University College of Law, jena.martin@mail.wvu.edu

Follow this and additional works at: https://researchrepository.wvu.edu/faculty_publications

Part of the Business Organizations Law Commons, Criminal Law Commons, Human Rights Law Commons, International Humanitarian Law Commons, and the International Law Commons

\section{Digital Commons Citation}

Martin, Jena, "It's Complicated: The Challenge of Prosecuting TNCs for Criminal Activity Under International Law" (2019). Faculty Scholarship. 1132.

https://researchrepository.wvu.edu/faculty_publications/1132 


\title{
Indiana Int'l \& Comp. Law Review
}

Volume 29

Number 2

2019

\section{SYMPOSIUM}

\section{It's Complicated: The Challenge of Prosecuting TNCS FOR CRIMINAL ACTIVITY UNDER INTERNATIONAL LAW}

\begin{abstract}
JENA MARTIN ${ }^{*}$
"Holding multinational corporations accountable for their adverse impact on the full range of human rights directly under international law seems... intuitive. But it raises practical challenges of its own, quite apart from the doctrinal debate about corporations as "subjects" of international law."

\section{INTRODUCTION}

Like it or not, Transnational Corporations (TNCs) are taking an increasingly active role in larger societal issues and debates.

Whether it's a social advocacy campaign that seeks to reduce violence and bullying, ${ }^{2}$ a decision by a pharmacy company to stop selling tobacco products, ${ }^{3}$ or a sportswear company's decisions to take a stand in solidarity with an advocate's resistance to police brutality, ${ }^{4} \mathrm{TNCs}$ are becoming increasingly vocal

* Professor of Law, West Virginia University. This article was supported, in part, by a Hodges' Fund Faculty Research Grant. Many thanks to Wade Sockman and Emily Cramer for some much-needed assistance with research. Also, I am grateful for the support and insight of the following people: Valarie Blake, Amber Brugnoli, Rachel Chambers, Amy Cyphert, Kirsha Trychta, Elaine Wilson, and Tara Van Ho.

1. John Ruggie, A UN Business and Human Rights Treaty?, HaRvard KenNEDy School (2014), https://www.business-humanrights.org/sites/default/files/media/documents/ruggie-on-unbusiness-human-rights-treaty-jan-2014.pdf [https://perma.cc/X5QG-HU63].

2. Tovia Smith, Backlash Erupts After Gillette Launches a New \#MeToo-Inspired Ad Campaign, NPR (Jan. 17, 2019, 5:00 AM), https://www.npr.org/2019/01/17/685976624/backlasherupts-after-gillette-launches-a-new-metoo-inspired-ad-campaign [https://perma.cc/BJF2-ZS2Z].

3. We Quit Tobacco, Here's What Happened Next, CVS HEALTH, https://cvshealth.com/ thought-leadership/cvs-health-research-institute/we-quit-tobacco-heres-what-happened-next [https://perma.cc/Q8CG-7QS9].

4. Manish Dudharejia, 4 Branding Lessons From Nike's Colin Kaepernick Ad, ENTREPRENEUR (Oct. 22, 2018) https://www.entrepreneur.com/article/321130 [

https://perma.cc/SVS6-A8V2]. Since the ad campaign, Nike has furthered their support of Kaepernick in their new endorsement contract, which features a contribution to his charity 'Know Your Rights.' Hallie Detrick, The Little-Known Charity That Will Benefit From Nike's New Contract With Colin Kaepernick, FoRTUNE (Sept. 4, 2018), http://fortune.com/2018/09/04/colin- 
regarding their role in larger societal issues. ${ }^{5}$ But there is a darker side to the increased intermingling between corporations and the larger societal impact; namely the potential for a corporation to be involved, or sometimes, at the heart of, crimes against humanity. ${ }^{6}$

As a result of the increased allegations levied against corporations for these types of violations, ${ }^{7}$ having corporations criminally prosecuted is a top priority for many business and human rights' (BHR) advocates who wish to hold TNCs accountable. ${ }^{8}$ The argument certainly engenders sympathy: in order for TNCs to reach the level of culpability to justify accountability under international criminal

kaepernick-nike-contract-donation-know-your-rights/ [https://perma.cc/T8MK-PJP3].

5. To be clear, the discussion regarding what role corporations can and should have in society has been discussed and debated for quite some time. Indeed, at least as far back as the early 1970s with Milton Freidman's now famous article in the New York Times, the debate both for and (as Friedman's article suggests) against corporate social responsibility and its closely related cousin, business and human rights, has occurred in the popular discourse. However, it is only within the last decade or so that these issues have taken on such an explicit framework. See Jena Martin Amerson, The End of the Beginning? 17 Fordham J. CORP. \& Fin. LAW 871 (2012); Milton Friedman, The Social Responsibility of Business is to Increase Profits, N.Y. TIMES MAGAzINE (Sept. 13, 1970), http://umich.edu/ thecore/doc/Friedman.pdf [https://perma.cc/36FG-2HJQ].

6. Crimes against humanity is defined by the $\mathrm{UN}$ as a deliberate act, typically as part of a systematic campaign, that causes human suffering or death on a large scale. Crimes Against Humanity, United Nations Office on Genocide Prevention and the Responsibility to PROTECT, http://www.un.org/en/genocideprevention/crimes-against-humanity.shtml [https://perma.cc/L6D3-QHKR]. The types of crimes that can fall into this category include: genocide, systemic rape, deportation of a population by force and; enslavement. Rome Statute of the International Criminal Court art. 7, July 17, 1998, 2187 U.N.T.S. 90 [Hereinafter Rome Statute].

7. See generally Emma Broches, Accountability for the Syrian Regime: An Overview, LAwFARE BlOG, (Mar. 5, 2019, 8:00 AM), https:/www.lawfareblog.com/accountability-syrianregime-overview [https://perma.cc/9BPV-D34V]; Nick Cumming-Bruce, Oil Companies May Be Complicit in Atrocities in South Sudan, U.N. Panel Says, N.Y. Times, (Feb. 20, 2019), https://www.nytimes.com/2019/02/20/world/africa/south-sudan-oil-war-crimes.html [https://perma.cc/L3BG-RBXS]; Caitlin Schroering, Brazil Dam Collapse Is a Human Rights Disaster and Crime, TRUTHOut, (Mar. 3, 2019), https://truthout.org/articles/brazil-dam-collapse-isa-human-rights-disaster-and-crime/ [https://perma.cc/CPF7-35NZ].

8. For instance, Amnesty International and the International Corporate Accountability Roundtable developed an extensive report, entitled the Corporate Crimes Principles which aims to address what they entitle the "impunity gap" for corporations and their executives who commit crimes in furtherance of their job. THE INDEPENDENT COMMISSION OF EXPERTS, THE CORPORATE Crimes Principles: Advancing Investigations and Prosecutions in Human Rights Cases (Oct. 2016), https://www.commercecrimehumanrights.org/wp-content/uploads/2016/10/CCHR0929-Final.pdf [https://perma.cc/NWZ7-H9ZV] [hereinafter THE PRINCIPLES]. Specifically, the Introduction notes that "when corporate actors, including corporate entities or individuals acting on behalf of a corporate entity, commit or are complicit in the commission of crimes linked to human rights abuses, accountability all too rarely follows. Id. at i. 
law, some horrendous acts must have occurred. Whether in the area of exploitative labor practices, gross environmental impacts, or even complicity with genocide, victims of these crimes at the hands of TNCs have an understandable desire to want to see justice served.

But is using international criminal law to prosecute the TNC itself really the best course of action?

On the one hand, holding a corporation liable would align with the conceptual notion of the corporation as person - a concept that has been adopted in most contexts $^{9}$ and, as such, would satisfy those who wish to hold the TNC accountable. On the other hand, holding a TNC criminally liable under international law cannot be done without unpacking several layers at the intersection of corporate law, international human rights law, and criminal jurisprudence. ${ }^{10}$ As such, the aim of this essay is not to solve all the issues that are implicated by TNCs being prosecuted criminally under international law. Rather, my objective is to highlight some of the more pernicious issues offered by the current state of affairs and offer my initial thoughts regarding whether we should proceed and, if so, what should be considered. Specifically, part one of this essay will discuss the challenges inherent in the dualistic nature of the TNC frequently presenting itself as a unified organization, while at the same time strategically using its separate legal entities - and the enforcement implications that arise from that challenge. Part two will move on to the procedural challenges that arise from prosecuting a TNC (both domestically and internationally) before turning to part three, which will discuss the challenges under two areas of substantive law - namely corporate and criminal law. Taking all of the above into account, part four will then address whether, given all of these challenges, using international mechanisms to prosecute TNCs is, in fact, wise. To that end, part four will discuss some potential costs that could arise from a successful prosecution before examining some already established principles to see if they

9. One notable exception is found in the U.S. Supreme Court's decision in Jesner v. Arab Bank, PLC. According to the Supreme Court, corporations, at least foreign corporations, are not considered persons within the ambit of the Alien Tort Statute. Jesner v. Arab Bank, PLC, 138 S.Ct. 1386 (2018); See also Jeffrey Van Detta, Rubin v. Islamic Republic of Iran and Jesner v. Arab Bank, PLC:SCOTUS Trims to Statutory Boundaries The Recovery in U.S. Courts Against Sponsors of Terrorism and Human-Rights Violations Under FSIA and ATS, 29 IND. INT'L \& COMP. L. REV. (forthcoming 2019).

10. I should also note that my primary method of engaging with this topic at this stage is a theoretical one. While there are others who have discussed specific cases where business and human rights intersect (and indeed, in other jurisdictions there are specific business and human rights related cases where criminal charges have been brought) my aim at this stage is to unpack the jurisprudence to its bare elements in the hopes of discovering some new, perhaps, previously overlooked issue or policy concerns. For more practical discussion of specific cases in other jurisdictions see See Access to Legal Remedies for Victims of Corporate Human Rights Abuses in Third Countries, Directorate-General for External Policies 18 (2019), http://www.europarl.europa.eu/RegData/etudes/STUD/2019/603475/EXPO_STU(2019)603475 _EN.pdf [https://perma.cc/5ABK-3M7D] [hereinafter DROI Report]. 
may provide a way forward. ${ }^{11}$

As recent trends in international law would suggest, ${ }^{12}$ the cries of support for holding TNCs accountable for their role in human rights violations seems to be gaining traction. As such, it seems particularly timely - when the debate for the appropriate mechanism is still in its nascent stage $^{13}$ - to have a frank conversation regarding the challenges and underlying rationale for holding TNCs

11. One major caveat: because there is currently no mechanism to prosecute a corporate entity under international criminal law, this essay must by definition, be a thought exercise. The International Criminal Court (ICC) - the chief body for prosecuting criminal activity under an international framework - has no mechanism for attaching liability to a corporation and can, instead, only prosecute corporate executives for their role in criminal activity that falls within the ICC's jurisdiction. Rome Statute, supra note 5. Courts such as the International Criminal Tribunal for the former Yugoslavia (ICTY) and the International Criminal Tribunal for Rwanda (ICTR), implemented by statute in the wake of massive human rights abuses, are given the ability to focus legal punishment on perpetrators. See United Nations International Residual Mechanism for Criminal Tribunals, Mandates and Crimes under ICTY Jurisdiction, UNITED NATIONS International CRiminal TRIBUnAL FOR THE Former Yugoslavia, http://www.icty.org/ en/about/tribunal/mandate-and-crimes-under-icty-jurisdiction [https://perma.cc/L7AZ-7CB5]; The ICTR in Brief, United NATIONS InTERnAtional RESidual MEChanism For CRiminal TRIBUNALS, http://unictr.irmct.org/en/tribunal [https://perma.cc/4Y9V-7L4A]; Zoe B. Whaley, Timing Justice, Lessons from the Tribunals in Yugoslavia, Rwanda, Sierra Leone, and Cambodia, Political Science Honors Project Macalaster College (2009) https:/digitalcommons. macalester.edu/cgi/viewcontent.cgi?referer=https://www.google.com/\&httpsredir=1\&article=10 22\&context=poli_honors [https://perma.cc/XC4E-UEQV]. There are but a few specialized courts that have that power, and hear even fewer cases.. Nonetheless, there is merit to engaging in the thought exercise of prosecuting a corporate entity. To that end, drawing heavily on U.S. jurisprudence regarding corporate culpability, I will show that there are significant issues that can arise with prosecuting a TNC that should be considered within the international criminal law context.

12. Legally Binding Instrument to Regulate, in International Human Rights Law, the Activities of Transnational Corporations and Other Business Entities, U.N. Humans Rights OFFICE OF THE High COMMissioner (July 16, 2018), https://www.ohchr.org/documents/ hrbodies/hrcouncil/wgtranscorp/session3/draftlbi.pdf [https://perma.cc/W84H-Y4BU].

13. To be clear, I am not the first scholar to engage in any one of these issues. Infra articles in part four. Given the development of a business and human rights treaty (see infra note 49) many scholars, in fact, have specifically stated that issue of corporate criminal liability should be handled within such a treaty. See Nadia Bernaz, An Analysis of the ICC Office of the Prosecutor's Policy Paper on Case Selection and Prioritization of Business and Human Rights, Journal OF International CRiminal Justice at 6 (2017). For another comprehensive treatment of legal remedies for corporate human rights abuses see JENNIFER ZWERK, CORPORATE LIABILITY FOR Gross Human Rights Abuses: Towards a Fairer and More Effective System of Domestic Law Remedies, Office of the UN High Commissioner for Human Rights (2013), https://www.ohchr.org/Documents/Issues/Business/DomesticLawRemedies/StudyDomesticeLa wRemedies.pdf [https://perma.cc/E8U6-MDV5]. 
accountable under international criminal law. ${ }^{14}$

\section{THE DUALITY OF THE TNC AND THE CONUNDRUM OF CULPABILITY}

In the world of corporate entities, there is often a consistent gap between the $\mathrm{TNC}$ as a brand and the TNC as a legal person. The duality regarding the perception and the reality of TNCs is not, perhaps, accidental. TNCs have spent a significant amount of revenue attempting to craft a uniform image - a brand of itself that extends far beyond the specific legal personality of a particular jurisdiction. ${ }^{15}$ For instance, part of what McDonald's hopes attracts consumers to their stores is the probability that the customer will have the same experience having a Big Mac in Vevay, Indiana as they will in Geneva, Switzerland, ${ }^{16}$ even if the former is operated by a small franchisor and the latter is owned by a subsidiary of the McDonald's Corp. in the U.S. To date, these efforts by TNCs have been successful. Unfortunately, this duality also extends to the perception consumers and communities have when scandals and criminal acts are reported that somehow touch on a TNC, even if the specific corporation at issue is not involved. ${ }^{17}$ When accusations regarding the use of child labor happen in the Democratic Republic of Congo, where children as young as seven are allegedly working in the mines, ${ }^{18}$ touch on corporations with securities reporting obligations in the U.S., ${ }^{19}$ or a chemical leak happens in Bhopal, India that implicates the same corporation that has facilities in Institute, West Virginia, ${ }^{20}$

14. For the purposes of this essay, the domestic lens that will be applied will be a U.S. oriented one.

15. See generally Claude Serfati, Financial dimensions of transnational corporations, global value chain and technological innovation, 2 DANS JouRnAL OF INNOVATION ECON. \& MGMT. 35 (2008) https://www.cairn.info/revue-journal-of-innovation-economics-2008-2-page-35.htm\# [https://perma.cc/73AZ-342T].

16. 50 Years of the Big Mac, McDonalds Newsroom (Aug. 1, 2018), https://news. mcdonalds.com/stories/our-food-details/big-mac-50-history-infographic [https://perma.cc/2CE4LA45]

17. See Steve Boggan 'We Blew It:' Nike Admits to Mistakes Over Child Labor, Common DrEAMS (Oct. 20,2001), https://www.commondreams.org/headlines01/1020-01.htm [https://perma. cc/QH39-HHVM]; Stephen Foley, Apple admits it has a human rights problem, INDEPENDENT (Feb. 14, 2012), https:/www.independent.co.uk/news/world/asia/apple-admits-it-has-a-humanrights-problem-6898617.html [https://perma.cc/LDT4-V7VR].

18. It was these types of concerns in particular that gave rise to language within the DoddFrank act directing the SEC to engage in rulemaking surrounding corporate obligations to report the use of minerals that have been sourced from the Democratic Republic of Congo. The SEC's subsequent rulemaking has been the source of great controversy and ultimate defeat. See Jena Martin, Hiding in the Light: The Misuse of Disclosure to Advance the Business and Human Rights Agenda, 56 CoL. J. TRAN. L. 530 (2018).

19. Id.

20. Ben A. Franklin, Toxic Cloud Leaks at Carbide Plant in West Virginia, N.Y. TIMES (Aug.

12, 1985), https://www.nytimes.com/1985/08/12/us/toxic-cloud-leaks-at-carbide-plant-in-west- 
society is pre-conditioned to attach liability 'in the court of public opinion' to the $\mathrm{TNC}$, even if the specific corporate entity itself is not to blame. ${ }^{21}$ In short, TNCs have been effective at blurring lines so that we think of them as a giant monolithic when, in fact, they are linked through wholly owned and partially owned subsidiaries or, (even more attenuated) through independent vendors within a supply chain. ${ }^{22}$ The TNC's duality also informs the challenges prosecutors face, both procedurally and substantively, in holding these corporations criminally accountable. ${ }^{23}$

\section{THE CHALLENGES IN PROCEDURAL LAW}

Among the hosts of issues that arise in bringing particularly egregious TNC behavior to justice, the most pernicious one is regarding the process with which to do so. This idea of process raises a number of issues under international law: everything from the venue, to the political will needed, ${ }^{24}$ to the jurisdictional power, to the seemingly more mundane (but equally compelling) issue for impacted communities, of logistics. ${ }^{25}$ This essay will discuss only a small subset

virginia.html [https://perma.cc/N54G-QJPC].

21. See generally Paul Courson, Public perception of BP affected spill response, Allen says, CNN (Sept. 27, 2010), http://www.cnn.com/2010/US/09/27/gulf.oil.disaster/index.html [https://perma.cc/78QN-R2CP]; Burhan Wazir, Nike accused of tolerating sweatshops, THE GUARDIAN (May 19, 2001), https:/www.theguardian.com/world/2001/may/20/burhanwazir. theobserver [https://perma.cc/SH9X-S7MW].

22. For instance, Apple has over 200 suppliers that make up $97 \%$ of its procurement list. Supplier List, APPLE (2019), https://www.apple.com/supplier-responsibility/pdf/Apple-SupplierList.pdf [https://perma.cc/R6UB-HNTE].

23. There are numerous examples of criminal cases that have been brought against TNCs in jurisdictions outside of the United States. For instance, a recent study convened by the European Parliament, identified 35 cases of human rights abuses (both civil and criminal) allegedly perpetrated by corporations in the European Union alone. See DROI Report, supra note 10. While a full review of the cases analyzed in the study are outside the scope of this essay, the study's findings regarding twelve of the cases chosen for in-depth review demonstrate that, to date, none have resulted in a corporation being held liable for human rights abuses. Id. at $104-106$. In addition, many of the barriers to justice identified in the study are in line with the issues raised in this essay, including: "Access to evidence; costs of bringing claims; safety of witnesses; time barriers; culture and/or language barrier." Id. at 103.

24. The issue of political will can be tied both to foundational concerns a prosecutor might have but also the necessary decisions regarding how to prioritize prosecutions, given the limited resources available to law enforcement.

25. This, in turn, raises a host of subsidiary issues that include, how to call witnesses, in what language to conduct the trial, who speaks for the corporation and how you overcome the transportation barriers that are often insurmountable for witnesses. See, e.g., Susan Lamb's lecture on the issues raised by the Cambodia trial. WVU Law, McDougal Lecture Series - Spring 2019, YouTube (Jan. 15, 2019), https://www.youtube.com/watch? $\mathrm{v}=\mathrm{e}-\mathrm{RBDA} 2 \mathrm{jBS} 8 \& \mathrm{t}=9 \mathrm{~s}$ [https://perma.cc/7KU7-VGN9]. 
of those issues - namely examining the jurisdictions in which these proceedings should be held. ${ }^{26}$ Specifically, the next sections will discuss both the use of U.S. domestic litigation to tackle extraterritorial behavior and the use (largely theoretical at this point) of international venues, in particular the International Criminal Court (the "ICC").

\section{A. Domestic Courts Using Extraterritoriality Applications}

On the domestic level, attempts to hold TNCs accountable (civilly and criminally) have been met with unfettered corporate resistance. For instance, in the United States, corporations have levied vigorous defenses against human rights advocates' attempts to use the Alien Tort Statute (ATS) as a vehicle to hold TNCs liable. ${ }^{27}$ The strategy appears to have been, at least partially, effective. ${ }^{28}$ In 2018, the U.S. Supreme Court held foreign ${ }^{29}$ corporations could not be brought within the ambit of the ATS. ${ }^{30}$ While there is some movement in other jurisdictions $^{31}$ to provide victims of human rights abuses with the ability to hold

26. While, by its nature, raising the procedural issues also implicates the substantive issues (specifically regarding what law to apply), I will, for the sake of logical structure, leave those issues to the next section.

27. See, e.g., Doe v. Unocal, 248 F.3d 915 (9th. Cir. 2001) (affirming a lack of minimum contact necessary to establish personal jurisdiction); Bowoto v. Chevron, 621 F.3d 1116 (9th Cir. 2010) (upholding a district court's barring of ATS wrongful death and survival claims as preempted by DOHSA); Kiobel v. Royal Dutch, 621 F.3d 111 (2nd Cir. 2010) (holding corporate defendants not subject to ATS liability because they were not subject under customary international law); Jesner v. Arab Bank, PLC, 138 S.Ct. 1386 (2018) (holding that without express intent from Congress, courts could not extend ATS liability to foreign corporations).

28. Jesner v. Arab Bank, PLC, 138 S. Ct. (2018). Although the door may still be open to hold domestic corporations liable under the ATS, it is unlikely advocates will bring about such a challenge with so much negative precedent.

29. For a discussion of Jesner's impact on future litigation involving domestic corporations, see William Dodge, Jesner v. Arab Bank: The Supreme Court Preserves the Possibility of Human Rights Suits Against U.S. Corporations, Just SECURITy (Apr. 26, 2018), https://www.justsecurity. org/55404/jesner-v-arab-bank-supreme-court-preserves-possibility-human-rights-suits-u-scorporations/ [https://perma.cc/QYB6-TW83].

30. What's interesting about the ATS is that it marks the departure from the typical strategy of holding corporations liable for white collar crimes. Specifically, in order for corporations to fall within the ambit of the ATS there must first be a crime against humanity. Sosa v. Alvarez-Machain, 542 US 692 (2004). The irony, of course, is that a crime against humanity under international law only translates to a tort under U.S. jurisdiction (through the ATS) - there is no parallel criminal jurisdictional statute. This also highlights the fact that, under U.S. criminal law, most of the crimes that TNCs have been found to have violated have been white collar crimes instead of the more atrocious crimes against humanity.

31. Australia's Criminal Code expressly discusses the liability of corporate bodies and Indonesia has recently pursued criminal prosecution of TNCs in regards to environmental law violations. Anita Ramasastry \& Robert C. ThOmpson, Commerce, Crime And Conflict: 
corporations accountable, the significant limitation of the ATS has, practically speaking, curtailed extraterritorial civil litigation against corporate entities. ${ }^{32}$

One way to potentially circumvent the issues of extraterritoriality would be for prosecutors to find a nexus between the corporation's activities within its home state (usually the jurisdiction where the headquarters sits) and the activities of its subsidiaries within the host state. So, for instance, if a prosecutor could find a connection between the decisions of the parent corporation's board of directors and the specific actions of its subsidiary to effectuate that decision, then perhaps a link could be established that would establish jurisdiction for the parent corporation. Unfortunately, criminal prosecutions that have been built around attempting to find such a nexus have been met with limited success. ${ }^{33}$

In addition, cross border claims against corporations raise a number of practical issues. For instance, according to one report developed by human rights advocates, the particular challenges for prosecuting corporate cross border crimes include the disparity between the ease with which corporations can operate and the limitations on state actors. ${ }^{34}$ Specifically, the report notes that:

Multinational corporate entities act across borders with ease due to developments in technology as well as favourable corporate, trade and investment laws. They exercise significant power and influence. Laws to

Legal Remedies for Private Sector Liability for Grave Breaches of International LaW 13-14, https://www.biicl.org/files/4364_536.pdf [https://perma.cc/E7ZS-TX27]. The UK has also made strides in holding corporate entities liable with a new asset forfeiture law that attaches to corporate human rights abuses. Fabio Leonardi, William M. Sullivan Jr., \& Mattew Oresman, Retroactive Corporate Liability for Human Rights Abuses, Pillsbury, (Dec. 7, 2017), https://www.pillsburylaw.com/en/news-and-insights/retroactive-corporate-liability-for-humanrights-abuses.html [https://perma.cc/E3ZH-4C4E].

32. Also, the civil nature of these mechanisms means that it is not a tool that is used by criminal prosecutors. In Kiobel v. Royal Dutch Petroleum Co., the Court explained in dicta that a plaintiff cannot file an ATS claim unless it "touch[ed] and concern[ed] the territory of the United States". Kiobel v. Royal Dutch Petroleum, 569 U.S. 108, 126 (2013). However, the Second Circuit has held that Kiobel absolutely barred any ATS claim that was based on conduct which happened abroad. Balintulo v. Daimler AG, 727 F.3d 174, 182 (2d. Cir. 2013). These case are but two that showcase the split in determining whether an ATS claim would still be viable. See also Eric Engle, Extraterritorial Corporate Criminal Liability: A Remedy for Human Rights Violations?, 20 ST. JoHN's J. LEGAL COMMENT. 287 (2006).

33. See, e.g. Amnesty International, InJustice InCORPorated 122-31 (2014), https://www.amnesty.org/download/Documents/8000/pol300012014 en.pdf [https://perma.cc/6LKN-S9S6] (discussing the legal barriers to bringing an extraterritorial action). In the United States, recent Supreme Court jurisprudence around issues of jurisdiction and TNCs would seem to suggest that criminal prosecutions for extraterritorial conduct would also be met with limited success. See Daimler AG v. Bauman, 571 U.S. , 134 S. Ct. 746 (2014) (holding that a plaintiff cannot establish jurisdiction over a parent company based upon the acts of its subsidiaries that took place outside of the country).

34. The PRINCIPLES, supra note 8 , at 9. 
protect human rights and deter companies from committing wrongful acts have not kept pace with these developments. For example, the issues of separate legal personality and limited shareholder liability present significant legal challenges for accountability where the case involves a parent company based in a home State that operates through a local subsidiary or joint venture in the host State. This "governance gap" has created an environment in which corporate actors are able to commit serious human rights abuses and other corporate crimes with little accountability for doing so. ${ }^{35}$

In the end, prosecutors are at once fully aware of the challenges of bringing a transnational case against multiple corporate entities ${ }^{36}$ leading many, perhaps, to be fearful of the public's reaction if the challenges of prosecuting multiple entities proves to be insurmountable. ${ }^{37}$ As such, under the current domestic framework, at least within the United States, exercising jurisdiction against TNCs for acts committed abroad seems problematic.

In theory, then, an international venue would overcome many of the issues raised by cross border investigations. However, it would also raise several other concerns.

\section{B. International Venues}

Currently, there are a limited number of venues that could tackle the issue of holding TNCs liable for international criminal law violations. ${ }^{38}$ Chief among them

35. Id. This issue is exacerbated when the corporation may not be directly involved in the specific legal issue, but rather the criminal behavior is done by an actor within its supply chain. See Martin, supra note 18.

36. The PrinciPles, supra note 8, Principle Five, Commentary (stating that investigators and prosecutors "recognised that obtaining evidence and assistance in cross-border corporate crimes cases can be especially challenging.")

37. To wit, it would seem a perfectly reasonable concern of prosecutors that their failure to overcome the jurisdictional and personality hurdles posed by the TNC (see infra for details) could lead to public approbation that TNCs were getting off on a technicality. $C f$. Hot Coffee (2011) (the documentary that explores the public perception of a litigant who won a multi-million suit against McDonald's for burns she sustained after spilling McDonalds' coffee on herself. As the filmmakers show, the public's perception of the plaintiff (including one person who alludes to "jackpot justice") is at odds with the factual evidence that was shown (i.e., that she sustained third degree burns near her genitalia and was in danger of losing her life). See also Hot CoffEE, http://www.hotcoffeethemovie.com/default.asp?pg=thefilm [https://perma.cc/B9K4-ZRHW]; German Lopez, What a lot of People got Wrong about the Infamous 1994 McDonald's Hot Coffee Lawsuit, Vox (Dec. 16, 2016), https://www.vox.com/policy-and-politics/2016/12/16/13971482/ mcdonalds-coffee-lawsuit-stella-liebeck [https://perma.cc/R8PV-WLVR].

38. See Alice de Jonge, Transnational corporations and international law: bringing TNCs out of the accountability vacuum, 7 Critical Perspectives on InT'L Bus. 66 (2011); Suyan Droubi, Transnational Corporations and International Human Rights Law, 6 NOTRE DAME J. INT'L \& COMP. L. 119 (2016). 
would be the ICC. ${ }^{39}$ The types of crimes within the ambit of BHR advocate portfolios, including trafficking and forced labor, could theoretically fall under the jurisdiction of the ICC. In fact, these types of violations fall squarely within the ICC's mission which, it states, is to: "help put an end to impunity for the perpetrators of the most serious crimes of concern to the international community as a whole, and thus to contribute to the prevention of such crimes." ${ }^{\prime 40}$

In addition, the ICC is a fairly unusual creature of international law; although it followed the rules of treaty ratification (i.e., with states agreeing to be bound) it has jurisdiction over individuals instead of state parties. ${ }^{41}$ As such, individual actors can be prosecuted if their state is a party to the convening statute. Although prosecutions that proceed under the ICC's authority involve crimes against humanity, genocide, and war crimes, ${ }^{42}$ the ICC has jurisdictional power over any individual who is complicit in these acts, including corporate executives. ${ }^{43}$

Despite these advantages, the ICC remains a problematic option. Foremost, the foundational statute does not allow the prosecution of corporations. ${ }^{44}$ In order to overcome such a limitation then, all convening state parties would have to agree to amend the treaty, an arduous process under the best of circumstances but one that seems particularly problematic in the current environment. ${ }^{45}$

39. The ICC, currently in its seventeenth year, was hailed at the time of its inception and supported by many, getting the requisite 60 signatures easily. However, today some of those signatory nations have gone so far as to declare they do not agree to be bound, such as the United States. Jamie Mayersfield, Who Shall be the Judge?: The United States, the International Criminal Court, and the Global Enforcement of Human Rights, 25 Human Rights Q. 94-95(2003). In addition to the ICC, there are other international tribunals which could, in theory, examine corporate liability, however, with the exception of the Special Tribunal of Lebanon (the STL), none have actually held a legal person liable. For an in-depth discussion of the STL decision establishing corporate liability see Caroline Kaeb, The Shifting Sands of Corporate Liability under International Criminal Law, 49 GeO. WASH. INT'L L. REV. 351, 364 - 71 (2016).

40. Understanding the International Criminal Court, ICC, 1, https://www.icc-cpi.int/iccdocs/ PIDS/docs/UICCGeneralENG.pdf [https://perma.cc/LL4C-VWFJ].

41. In that sense, it differs from the other treaties which are primarily mechanisms for holding States (or countries) as duty bearers accountable under international law.

42. A person convicted in the ICC is subject to either (1) imprisonment for a specified number of years, not to exceed 30 or (2) a term of life imprisonment, when justified. Rome Statute, supra note 5, at art. 77(1). Convicted persons are also subject to additional penalties which may include (1) a fine or (2) a forfeiture of property derived directly or indirectly from the crime of which he was convicted. $I d$. at art. 77(2). At the conclusion of trial resulting in a guilty verdict, the convicted person serves their prison sentence in a member-state designated by the Court which have indicated their willingness to accept convicted persons. $I d$. at art. 103(1)(a). The conditions of the convicted person's imprisonment are then determined by both the Court and the member-state accepting the sentenced person. $I d$. at art. 103(1)(b).

43. Understanding the International Criminal Court, supra note 32.

44. Art. 25(1) of the Rome Statute of International Criminal Court provides jurisdiction over "natural persons" only.

45. In a report conducted by Amnesty International, concerning four case studies of business 
One solution perhaps would be to focus on prosecuting individuals at the head of the TNCs rather than the TNC itself . To that end, in 2003, the ICC's chief prosecutor, Luis Ocampo, stated that he would examine the role of business leaders as "accomplices in international crimes." ${ }^{46}$ However, despite $\mathrm{Mr}$. Ocampo's attempts, these efforts have not borne fruit. As one commentator remarks, "investigations initiated by the Office of the Prosecutor may have shown that prosecuting business activities is a more demanding task than anticipated or, in light 'of the ICC's complementary function, may not be of sufficient gravity to justify further action." ${ }^{47}$ In a 2016 policy paper the ICC has indicated that it is focusing on investigating corporate executives who engage in land grabbing (particularly in times of conflict), ${ }^{48}$ however, to date they have not done so. ${ }^{49}$

and human rights abuses, the organization determined that "some of the most significant obstacles to remedy are due not to legal factors but to the actions of companies, in particular their influence over governments and regulatory systems." AMNESTY INTERNATIONAL, INJUSTICE INCORPORATED 173 (2014), https://www.amnesty.org/download/Documents/8000/pol300012014en.pdf [https:// perma.cc/VD7B-HZRQ].

The report goes on to note that the leverage that corporations have over regulatory actors, even states themselves, are such that corporate influence almost certainly plays a role in the political will (or lack thereof) for a prosecutor to bring an action against a TNC or a state to amend a treaty to provide for more robust prosecutions of TNCs. Indeed, the report goes on to note that corporate lobbying is a significant method used to influence state actors at both the national and international level. Id. at 180. See also Rachel Chambers \& Alex Batesmith, Options for CRiminal Prosecution of UK COMPANIES For Human Rights ABuses CommitTed Outside of ENGLAND AND WALES 3 (May 2015)(stating that "the fact that there have been so few prosecutions of companies for any [corporate human rights abuses] suggest two alternatives: either the English criminal law is inadequate tp protect overseas victims of human rights abuses committed by UK companies and their subsidiaries, or that there is a lack of political will to prosecute within the UK.")

46. Hans Vest, Key Issues de lege lata; Definitions of Crimes and Attribution of Responsibility, 8 J. OF INT'L CRIM. JUST. 851 (2010).

47. Id. at 852 . Specifically, Vest notes that the banality of corporate activity can still be liable under international criminal law - if it in some way helps to promote the committing of atrocities. As Vest writes: "in theory, no business activity, regardless of how ordinary or 'neutral' it seems to be, can explicitly be left outside the scope of, e.g. accessorial liability to the commission of an international crime. Scenarios may cover providing raw materials, any kind of semi-finished products, end-products such as, e.g. weapons, goods and services including personal, technical and logistical assistance, information, cash, credit and banking facilities." Id. at 852. However, the nature of these activities also makes it more difficult to collect evidence and investigate.

48. Office of the Prosecutor: Policy Paper on Case Selection and Prioritisation, INT'L CRIM. CT. (Sept. 15, 2016), https://www.icc-cpi.int/itemsDocuments/20160915_OTPPolicy_Case-Selection_Eng.pdf [https://perma.cc/EQ4C-7756].

49. See Bernaz, supra note 13, at 2-3 (noting that the new policy paper has attracted a range of responses from the business and human rights field, ranging from the positive (a potential "tool to achieve justice for victims") to the dismissive (viewing the paper "as mere talk unlikely to lead to any real change."). In other venues, however, there does seem to be more movement towards 
Theoretically, then, while the ICC seems to be a compelling venue for the prosecutions of corporate related crimes against humanity, it seems as if the current political will renders this an unlikely alternative. In addition, even if the political will were found amongst the relevant decision makers, the implementation of such a program would lead to a host of logistical issues that would protract an already extenuated process. ${ }^{50}$

In addition, as the next section demonstrates, given the hurdles that have arisen in the U.S. when corporate and criminal law have intersected, trying to undergo corporate prosecutions under international law, where many of these issues can be magnified, ${ }^{51}$ could lead to a similar exacerbation in the challenges present. $^{52}$

\section{THE CHALLENGES IN SUBSTANTIVE LAW}

The hurdles that abound in applying the substantive law to TNCs are daunting. The issues take place in two primary areas of jurisprudence - corporate and criminal law.

\section{A. Corporate Law}

There are two seemingly incompatible trends taking place in U.S. corporate law today - increasingly providing corporations with rights, including

using international human rights law to hold TNCs accountable for abuses. For instance, in 2018, the UN Human Rights Council issued a zero-draft treaty on business and human rights. The purpose of the treaty is to "strengthen the respect, promotion, protection and fulfilment of human rights in the context of business activities of transnational character;" LEGALLY BINDING INSTRUMENT TO Regulate, in International Human Rights Law, the Activities of Transnational Corporations and Other Business Enterprises, Office of the United Nations High COMMISSIONER FOR HUMAN Rights, art. 2 (July 16, 2018), https://www.ohchr.org/Documents/ HRBodies/HRCouncil/WGTransCorp/Session3/DraftLBI.pdf [https:/perma.cc/JX58-L7FG]. Commentators for the treaty have said that the newly released draft needs to focus on protecting victims and requiring companies to do human rights due diligence. Doug Cassel, Treaty Process Gets Underway: Whoever Said It Would Be Easy?, Bus. \& Hum. RTs. Resource Ctr., https://www.business-humanrights.org/en/treaty-process-gets-underway-whoever-said-it-would-beeasy [https://perma.cc/85VL-D8Q3] . As such, short of a new or amended treaty, there is no room to hold TNCs liable under current international law.

50. For instance, any cross-border investigation would, presumably, need the cooperation of both the host state (where the violations occurred) and the home state (where the TNC's headquarters are located). As such, any difficulties that normally arise with inter-agency cooperation would only be magnified when each agency works under a different, sovereign, nation.

51. WVU Law, supra note 21.

52. Another specific issue that, while outside the scope of this essay is nonetheless worth mentioning, is the significant issue of trying to develop a cohesive jurisprudential model for corporate criminal liability when there are so many distinct legal doctrines (i.e., common law, civil law, Sharia law) that would need to be addressed. 
constitutional rights, while limiting accountability for the entity as a whole. ${ }^{53}$ Both of these trends seem to arise from imbuing corporations with legal personality. As a result, while the corporate structure is in essence, a legal fiction, these legal fictions have nonetheless been given certain rights under U.S. law. ${ }^{54}$ For instance, a corporation can sue and be sued in its own name. ${ }^{55}$ It can also own property, hold accounts in its own name and legally undertake many of the same actions of an individual human being. ${ }^{56}$ In addition, the corporation has grown exponentially in the last century. ${ }^{57}$ While originally it was designed as a way of pooling resources and acting within a very limited corporate charter given by the state, it has now become a ubiquitous business structure. ${ }^{58}$ This evolution has also resulted in the TNC.

Despite being imbued with legal personality, TNCs are nonetheless difficult to hold accountable. By definition, a TNC is a multinational enterprise, with subsidiaries that cross jurisdictional boundaries. ${ }^{59}$ Specifically, a TNC arises when a corporation creates a wholly-owned but legally separate entity (or several legal entities) known as subsidiaries. ${ }^{60}$ The purpose of the subsidiary can be varied, but often it is created specifically to further shield the parent company from liability. ${ }^{61}$ Under this structure, the original corporation becomes known as

53. Binyamin Appelbaum, What the Hobby Lobby Ruling Means for America, N. Y. TIMES (July 22, 2014), https://www.nytimes.com/2014/07/27/magazine/what-the-hobby-lobby-rulingmeans-for-america.html [https://perma.cc/M5XS-4UUQ] (discussing the Supreme Court ruling that corporations with religious owners cannot be required to pay for insurance coverage of birth control).

54. Some scholars, such as Stephen Bainbridge, have devised alternative theories for conceptualizing the corporation. For instance, Bainbridge discusses the corporate structure, particularly board of directors, as a nexus of contracts around which costs and transactions are organized. Stephen Bainbridge, The Board of Directors as Nexus of Contracts: A Critique of Gulati, Klein \& Zolt's 'Connected Contracts' Model (UCLA, School of Law Research Paper No. 02-05, Jan. 2000), https://ssrn.com/abstract=299743 [https://perma.cc/677G-A26S].

55. See, e.g., Model Business Corporations Act $\S 3.02$ (2016)(stating "unless its articles of incorporation provide otherwise . . every corporation has the same powers as an individual to do all things necessary ... including, without limitation power: (a) to sue or be sued."

56. Id.

57. See generally What is the history of corporations in America?, INVESTOPEDIA, (Aug. 29 2018), https://www.investopedia.com/ask/answers/041515/what-history-corporations-america.asp [perma.cc/GHM2-ZSS6].

58. See generally id.

59. See Grazio Ietto-Gillies, Transnational Corporations and International Production: Concepts, TheOries ANd EFFECTs 25 (2012) (stating “Transnational corporations (TNCs) are incorporated or unincorporated enterprises comprising of parent enterprises and their foreign affiliates.")

60. $I d$.

61. The general rule of corporate law is that parent companies are not liable for the actions of their subsidiaries. However, there is an exception - when a court finds evidence to warrant piercing the corporate veil (or establishing enterprise liability). These instances mainly occur when 
the parent company to the subsidiary corporation. ${ }^{62}$ This is further complicated when these subsidiary corporations all operate outside the U.S., mostly in developing countries where the regulatory system is much weaker than in the home country. ${ }^{63}$ This situation becomes even more complex when these subsidiaries have their own subsidiaries and their ownership is spread across multiple shareholders that include other corporations or state-owned enterprises. In short, each of these subsidiaries are corporations with separate legal personalities and limited liability. And yet, rarely do prosecutors have the ability or desire to bring to justice each of the separate legal personalities that may be involved in a corporate conspiracy sufficient enough to trigger crimes against humanity. ${ }^{64}$

The duality inherent in corporate structures and their specific actors is further complicated by the numerous legal frameworks in which a corporation operates. For instance, using the corporate structure to commit illegal acts implicates the corporate law of the particular state in which the corporation in incorporated. If the corporation is publicly traded, then U.S. securities law violations may also be present. If that publicly traded corporation is, for instance, involved in bribing government officials in order to achieve their ends, then anti-corruption laws might also be implicated. All of that may occur in a single national framework. As noted earlier, these challenges are multiplied when there are different state actors involved.

In addition, the internal corporate structure and its purported purpose leads to a number of competing interests that can give rise to reckless behavior. The seminal case of Dodge v. Ford forms the basis for the enduring concept regarding the purpose of the corporation in the U.S. ${ }^{65}$ To wit, the corporation is viewed as a vehicle "organized and carried on primarily for the profit of the stockholders." This narrative underlies much of the jurisprudence that has been written over the years and also forms the basis of many of the key legal principles in U.S. corporate case law. The shareholder profit narrative also results in an inherent tension in the structure and purpose of a corporation. If a corporation can only act through its corporate officers, and the corporate officers are largely shielded from liability for its decisions, then there is a danger that corporate officers will make decisions largely for their own self-interest rather than for the best interest of the corporation's shareholders. Taken to an extreme, this could result in corporate officers acting recklessly and using the corporation as a vehicle to commit

the entities are operating as a single business enterprise, the subsidiary has no assets of its' own, or there is a fraudulent transfer of assets in an effort to avoid liability. Kyle Hulten, When is a Parent Company Liable for the Acts of a Subsidiary?, IVL BLOG, https://www.invigorlaw. com/when-can-a-subsidiary-create-liability-for-a-parent-entity/ [perma.cc/S6AJ-PSME].

62. Id.

63. The Pros and Cons of Setting Up a Foreign Subsidiary, SHIELDGo, https://shieldgeo.com/ the-pros-and-cons-of-setting-up-a-foreign-subsidiary/ [perma.cc/S86M-68PY].

64. The Principles, supra note 7.

65. Dodge v. Ford Motor Co., 170 N.W. 668 (Mich. 1919).

66. Id. at 684 . 
criminal acts. ${ }^{67}$

At a minimum, there are an overwhelming amount of choices that corporate executives need to examine when facing questionable business practices. As a result, it may often be tempting to make an unprincipled decision in haste. ${ }^{68}$ When those consequences lead to criminal activity, the challenge for law enforcement becomes that much more difficult: with agencies having to assess many of the same actions and decisions that a corporate officer must engage in after the fact, but now with an eye towards gathering evidence for prosecution. There is also an additional hurdle of having less embedded cooperation across agencies (since, despite the corporate legal constructs, managers will often have greater access to information within a corporation's subsidiaries and affiliates than outside investigators) and it is clear that law enforcement faces a herculean task in assessing criminal activity that takes place in multiple jurisdictions with multiple legal entities in play. ${ }^{69}$

There are also other stakeholders that can affect a corporation's structure and its governance framework. They may include: employees, suppliers, customers, creditors, and the communities where the corporation operates. ${ }^{70}$ While none of these stakeholders typically have formal representation within corporate law jurisprudence (i.e., corporate officers and directors are generally not required to put the interests of these stakeholders above the needs of shareholder profitability), ${ }^{71}$ these groups can secure influence and leverage with the

67. Despite the adversarial posture of a criminal investigation, precedent has shown that corporate cooperation is a crucial factor that government agencies weigh when deciding what penalties to assess against violators. Sally Quillian Yates, Memorandum for Assistant Attorney General: Individual Accountability for Corporate Wrongdoing, U.S. DEPT. OF Just., (Sept. 9, 2015), https://www.justice.gov/archives/dag/file/769036/download [perma.cc/PU7V-XBDJ]. Since a corporation is a multi-layered entity with multiple actors who could potentially be involved in violating laws or contributing to human rights abuses, internal audits and corporate self-reporting are concrete steps that an entity can take to minimize risk. Even if the investigation originated outside of the corporation (say from the victim of a human rights abuse), corporations can still mitigate their negative impact by fully and completely cooperating with law enforcement agencies.

68. John S. Hammond et al., The Hidden Traps in Decision Making, HaRv. Bus. Rev., (Sept.-Oct. 1998), https://hbr.org/1998/09/the-hidden-traps-in-decision-making-2 [perma.cc/DF4S$5 \mathrm{JV}]$.

69. Phillip I. Blumberg, Asserting Human Rights Against Multinational Corporations Under United States Law: Conceptual and Procedural Problems, 50 Aм. J. ComP. L. 493 (2002).

70. See, e.g., Niklas Egels-Zanden, TNC Motives for Signing International Framework Agreements: A Continuous Bargaining Model of Stakeholder Pressure, 84 J. OF Bus. ETHICs 529-47 (2009), https://doi.org/10.1007/s10551-008-9722-3 [https://perma.cc/RX2C-2HRZ] (providing qualitative research that shows that TNCs decision to engage in International Framework Agreements and other corporate social responsibility initiatives comes, in part, from stakeholder pressure, particularly from labor unions).

71. For a fuller discussion of the role of stakeholder influence in a corporate board's decision making duties, see Jena Martin, Business and Human Rights: What's the Board Got to Do With It? 2013 ILL. L. REv. 959, 971 (2013) (discussing the various theories of corporate governance and the 
corporation either through formal contracts (such as collective bargaining agreements for unionized employees) or through softer, reputational means (such as advocacy campaigns in communities where corporate policies impact social issues, like human rights).$^{72}$ However, where a corporation operates in a "weak governance zone" in which these stakeholders have only limited leverage, then the needs of these stakeholders (such as employees or vendors of the corporation) will take a backseat to the purpose of the corporation. ${ }^{73}$

In addition, while not all of the stakeholders listed above will have a direct impact on the legal liability of the corporation, they do have the ability to wield power and influence at the corporation. However, in assessing how likely a corporation or its stakeholders will be to cooperate in a criminal investigation, the purpose of the corporation and how it affects decisions within the corporate structure should not be ignored. ${ }^{74}$

\section{B. Criminal Law}

Contrary to popular belief, ${ }^{75}$ there have been a surprising number of corporations that have been indicted in the United States. ${ }^{76}$ Most of these prosecutions have led to settlements and, despite the narrative that arose in the wake of Arthur Andersen's indictment and subsequent demise, very few (if any) have resulted in the liquidation of the corporation. As such, there is some benefit to analyzing the issues and challenges that arise when attempting to prosecute a corporation for a crime.

Although the particular elements of a crime might differ, the heart of every crime has two facets: (1) the actus reus (the behavior or specific criminal action) and (2) the mens rea (the intent, or state of mind that accompanied those acts or actions). Each of these are exceedingly more complicated when the "person" committing the crime is a legal fiction. How does one assess that for a corporation? In the United States, the law has done so with the use of the

role of stakeholders within each paradigm).

72. See generally id. (discussing the ways that stakeholders can influence corporate behavior).

73. See, e.g., Kamil Omoteso \& Hakeem Yusuf, Accountability of Transnational Corporations in the Developing World: The Case for an Enforceable International Mechanism, 13

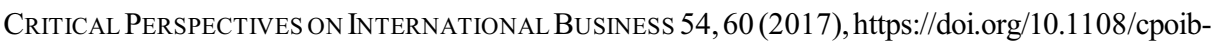
08-2014-0040 [https://perma.cc/2MHX-F7A6] (using Shell and Chevron's business focused interaction with the Nigerian government as a means to discussing the need for an international enforcement mechanism for TNCs in weak governance zones).

74. See J. Brooke Hamilton et al., Google in China: A Manager-Friendly Model for Resolving Cross-Cultural Ethical Conflicts, J. Bus. ETHICs (2009), https://www.researchgate. net/publication/225420561_Google_in_China_A_Manager-Friendly_Heuristic_Model_for_ Resolving_Cross-Cultural_Ethical_Conflicts [perma.cc/ESF9-3NKQ].

75. Gabriel Markoff, Arthur Andersen and the Myth of the Corporate Death Penalty: Corporate Criminal Convictions in the Twenty-First Century, 15 U. PENN. J. Bus. L. 797 (2013).

76. Id. 
respondeat superior doctrine. ${ }^{77}$ This concept allows courts to hold one person liable for the acts of its agents so long as the agents were: (1) acting within their scope of employment and (2) acting for the master's benefit. ${ }^{78}$ Once you have established, for instance, that a corporate executive intentionally used forced labor in the manufacture of basketball shoes, then you can use that theory to hold the master - in this case the corporation - liable for the executive's acts.

Many courts have wrestled with the scope of employment doctrine. As one commentator has noted, "[d] etermining exactly what constitutes conduct 'within the scope of employment' is a difficult task and the subject of numerous judicially developed rules and guidelines." 79 The factors that a court will consider to determine whether an employee was acting within the scope of her employment include: the employee's intent when performing the act; the nature, specific time, and place where the act occurred (i.e., whether at a relevant location or far away from the site); whether the act relates to the type of work that the employee was hired to do; whether the act was a reasonable outgrowth of the work that the employee was hired to do; and whether the employee in general had a reasonable amount of freedom in executing the acts ${ }^{80}$ Courts will also consider whether the conduct was done with some particular type of intent-whether for the benefit of the corporation, whether done with specific malice, whether the corporation (through its agents) were reckless in the behavior and that recklessness led to injury. ${ }^{81}$

There are several issues that complicate a corporate criminal case. Similar to other criminal investigations, when investigating allegations of corporate misconduct, it is rare to find direct evidence that points to one culpable executive who committed the criminal act. ${ }^{82}$ Rather, it is frequently several executives who are often working in tandem (or sometimes at cross-purposes) and whose conduct, as a whole, would fulfill the elements at issue but when examined compartmentally, may not. In short, while there may be several pieces of evidence that show several different executives were somewhat involved in a part of the act, there is often no one master puppeteer that put it all together. ${ }^{83}$

77. Latin for "Let the master answer."

78. Respondeat Superior, LEGALDICTIONARY, https://legaldictionary.net/respondeat-superior/ [perma.cc/N6HC-FZFP].

79. Hugh A. McCabe, Respondeat Superior, A Look at When Employers May be Held Liable for Their Employee's Conduct,

NeIL DymotT, http://www.neildymott.com/maecenas-mi-felis-mollis-vitae-mollis-ut-consecteturut-dolor [perma.cc/LR77-UQVX].

80. Id.

81. Id.

82. Peter Henning, Why It Is Getting Harder to Prosecute Executives for Corporate Misconduct, THE CLS BLUE SKY BLOG (June 13, 2017), http://clsbluesky.law.columbia.edu/ 2017/06/13/why-it-is-getting-harder-to-prosecute-executives-for-corporate-misconduct/ [perma.cc/K3YE-8ZSA].

83. See generally Michael E. Tigar, It Does the Crime But Note the Time: Corporate Criminal Liability in Federal Law, 17 AM. J. CRIM. L. 211 (1990). 
This was exactly what the defense argued in the Arthur Andersen case. On March 7, 2002, a federal grand jury indicted the U.S. accounting firm on one count of obstruction of justice. ${ }^{84}$ The firm was the auditor for then-energy giant Enron. ${ }^{85}$ During trial, Andersen's attorneys employed an explicit "Where's Waldo?" defense, arguing that the prosecution could not show that there was any one individual who was responsible for the acts alleged. While the defense's strategy was ineffective at trial, it did form a basis for the Supreme Court's reversal of the conviction in May 2005, ${ }^{86}$ although not before Arthur Andersen declared bankruptcy. ${ }^{87}$

In response to the difficulty of using respondeat superior for corporate criminal law, commentators have set forth alternate theories for holding corporations criminally liable. Here, I consider two models: the patchwork verdict model and the corporate ethos model, to see if they can be applied to any proposed international criminal law framework. ${ }^{88}$

For instance, Stacey Neumann $\mathrm{Vu}$, argues for what she calls a patchwork verdict. Under this theory, a jury could find liability in situations where it knows that something illegal has occurred but doesn't know which particular agent is responsible for the act in question sufficient enough to bring about respondeat superior liability. ${ }^{89} \mathrm{Vu}$ also makes the point that, in large organizations (such as

84. Edmund Sanders \& Jeff Leeds, U.S. Indicts Enron Auditor Over Shredding, Los Angeles Times (Mar. 15， 2002), http://articles.latimes.com/2002/mar/15/news/mn-32952 [perma.cc/68UB-ENMC].

85. Ironically, Enron, the company that hid billions of dollars in debt from failed projects and shook Wall Street, did not face criminal liability as an organization, although a number of its executives were charged with various counts of criminal securities violations. Id. See also Troy Segal, Enron Scandal: The Fall of a Wall Street Darling, InvestopediA (Feb. 9, 2015), https://www.investopedia.com/updates/enron-scandal-summary/ [perma.cc/K5KR-NLKH]; David Teather, Enron executives Lay and Skilling 'breached duty,' The GuARDiAn (Nov. 24, 2003), https://www.theguardian.com/business/2003/nov/25/corporatefraud.enron [perma.cc/UB6ZCTMB].

86. Arthur Andersen LLP v. United States, 544 US 696 (2005).

87. Unmesh Kher, The End of Arthur Andersen?, TIME (Mar. 11, 2002), http://content time. com/time/business/article/0,8599,216386,00.html [perma.cc/6W8L-NFRA].

88. Although outside the scope of this essay, there are other theories that have been implemented in other jurisdictions as a way of extending criminal liability to corporations. For instance, in Australia, the legislature has passed provisions in their Criminal Code that extend criminal liability to corporations. See Chambers \& Batesmith, supra note 45. Commentators also note that that "Australia has a somewhat progressive approach to the attribution of criminal responsibility through the notion of corporate culture." Id. at 20 . In providing their own recommendations regarding ways to expand UK law to allow for corporate criminal liability for actions committed overseas, the authors also noted that one possible tact, under UK law, would be to extend (or shift the guidance in UK's Bribery Act) to allow for UK corporations to be criminally prosecuted if senior management in the corporation's UK office evidenced a failure in management that led to human rights abuses. $I d$. at 28.

89. Stacy Neumann Vu, Corporate Criminal Liability: Patchwork Verdicts and the Problem 
TNCs), the idea of holding a corporation liable for the conduct of its agents becomes even more difficult in such a diverse environment. Alternatively, the Corporate Ethos Model $^{90}$ argues that corporations should be held criminally liable by examining the work of the corporation as whole. ${ }^{91}$ Specifically, they draw on the earlier work of Prof. Pamela Bucy ${ }^{92}$ who argued that you can examine eight factors to determine whether a corporation should be held liable. ${ }^{93}$ These eight factors include:

(1) The Hierarchy,

(2) Corporate Goals,

(3) Educating Corporate Employees About Legal Requirements,

(4) Monitoring Compliance with Legal Requirements,

(5) Investigating the Current Offense,

(6) Corporate Reaction to Past Violations and Violators,

(7) Compensation Incentives for Legally Appropriate Behavior, and

(8) Indemnification.

All of these factors focus on determining the corporation's ethos that contributed to the violation. ${ }^{94}$ As such, it is important when circumstantially determining a corporation's liability that the agent or actor was shown to have been encouraged by the corporation's ethos which then played a role in manipulating their actions. $^{95}$

While each of these models are a step forward from the current respondeat superior model, they also have similar limitations. Each model would seemingly require a more intensive evidence gathering strategy to make connections across various entities and subsidiaries. Moreover, as I suggest in the next section, even if these models were employed; under international criminal law, the consequences in their successful deployment might lead to larger societal challenges.

of Locating a Guilty Agency, 104 CoL. L. REV. 459, 460 (2004).

90. Nan Ellis \& Steven Dow, Attaching Criminal Liability to Credit Rating Agencies: Use of the Corporate Ethos Theory of Criminal Liability, 17 U. PA. J. Bus. L. 167, 189 (2014).

91. Id.

92. Pamela Bucy, Corporate Ethos: A Standard for Imposing Corporate Criminal Liability, 75 MinN. L. REV. 1095, 1099 (1991).

93. Id. Examples include: (1) whether the corporate management is aware of the illegal activities of their lower-level employees; (2) whether the activities of the employees were routine and embedded into the corporation; (3) whether the employees were acting under direct instructions from supervisors. Prosecutors could also consider expert testimony that would show the "time and expense" of being within the law compared to the actual acts of the corporation. See THE PRINCIPLES, supra note 7.

94. Id. at 1128 .

95. Id. 


\section{SHOULD A TNC BE HELD LIABLE UNDER INTERNATIONAL LAW?}

In contrast to the voluminous discussions by scholars regarding the potential impediments to the prosecution of a TNC, there has been relatively discussion regarding the negative consequences of their successful prosecution. Of those that have discussed this issue, one of the most enduring narratives that persists is that the prosecution of TNCs may in fact lead to their death. ${ }^{96}$ While, on the national level, at least one scholar, Gabriel Markoff, has shown that this is predominantly a false narrative (in fact U.S. corporations that are criminally prosecuted usually survive $)^{97}$ and, as such, adds an important element to the debate on corporate criminal convictions, it appears that, in the end, it may be inapplicable to the specific issue regarding prosecuting TNCs under international criminal law. The convictions that Markoff analyzed were almost exclusively based on financial crimes. ${ }^{98}$ Given the egregiousness of the types of crimes at issue (in that they are primarily crimes against humanity), one wonders if the public outcry if a corporation were to be convicted of these issues would be more significant and lead to stronger collateral consequences.

However, Markoff's study does implicate a facet of criminal law that is at the heart of holding corporations accountable. Specifically, how do you punish the corporation? You can't send it to jail. ${ }^{99}$ You can certainly condemn it to die ${ }^{100}$ by erasing its corporate charter and dissolving it. ${ }^{101}$ But then what impact will that have on surrounding communities? Like it or not, corporations, particularly TNCs, are incredibly powerful entities. ${ }^{102}$ As a result, liquidating the whole TNC structure, even if it were feasible, would likely lead to debilitating effects on all those affected by it. ${ }^{103}$ Dead corporations can hurt shareholders, communities,

96. In an empirical study of U.S. corporations, Prof. Markoff showed that (1) holding corporations criminally liable happens much more frequently than is commonly believed, and (2) a corporate criminal conviction almost never means the "death" (i.e., liquidation) of a corporation. Markoff, supra note 56.

97. Id.

98. Id.

99. Id. at 799 .

100. See Tim Worstall, "I'll Believe Corporations Are People When Texas Executes One”: What Is This Foolishness from Robert Reich?, ForBES (Nov. 17, 2012), https://www.forbes.com/ sites/timworstall/2012/11/17/ill-believe-corporations-are-people-when-texas-executes-one-what-isthis-foolishness-from-robert-reich/\#7d55f2f533f2 [perma.cc/85BP-47JS]. California has similarly tried to enact individual criminal punishments on a corporation through a three-strikes bill, where on the third strike a corporation is required to liquidate. Francie Grace, 3 Strikes And You're Out Of Business, CBS News (May 5, 2003), https://www.cbsnews.com/news/3-strikes-and-youre-outof-business/ [perma.cc/H8Y9-43NC].

101. Id.

102. Michael Ricciardi, Who Runs the World? - Network Analysis Reveals 'Super Entity' of Global Corporate Control, PLANETSAVE, https://planetsave.com/2011/08/28/who-runs-the-worldnetwork-analysis-reveals-super-entity-of-global-corporate-control/ [perma.cc/B5VK-BYWQ].

103. In truth, there are always collateral consequences for innocent bystanders of criminal 
employees and millions of other stakeholders. ${ }^{104}$ Also, would we just dissolve the parent corporation? The offending subsidiary? If so, where would that leave the rest of the corporate organ? The irony, of course, is that if a corporation is facing international criminal liability, then it will have probably had to have been accused of involvement with atrocities. ${ }^{105}$ If that's the case then not holding them accountable is just as problematic. ${ }^{106}$ Given all the challenges, the persistent question remains, should a corporation be held liable under international criminal law?

$$
\text { A. Maybe. . . }{ }^{107}
$$

When crimes against humanity involve businesses, there is some very real damage that TNCs can inflict. As such, impacted communities have a justifiable desire to see corporations punished through criminal law. ${ }^{108}$ As Ellis \& Dow

convictions. See, e.g., Amy Cyphert, Prisoners of Fate: The Challenges of Creating Change for Children of Incarcerated Parents, 77 MD. L. REv. 385, 387 (2018) (discussing the collateral consequences of criminal convictions on the defendant's "blameless children.").Perhaps then, the most significant difference for the conviction of a TNC is the order of magnitude regarding its impact on the community. For instance, one TNC could employ hundreds of thousands of people across the world. As such, the impact of its demise would cause immediate and potentially catastrophic damage to the global economy. It probably would have been better if we had never let them get that big - see, e.g., Joanne Bauer and Elizabeth Umlas, Has Their Time Come? A Tale of Two Corporate Responsibility Movements, The CLS BLuESKy BloG, http://clsbluesky.law. columbia.edu/2018/02/02/has-their-time-come-a-tale-of-two-corporate-responsibility-movements/ [https://perma.cc/W8UG-PMRT] (questioning "whether a company . . . can be too big to take human rights into account") - but at this point there seems to be no turning back.

104. Just think of the upheaval that would come if Walmart and all of its subsidiaries were to be dissolved.

105. International criminal courts can only hear violations of human rights. See sources cited supra notes 5 and 10 and accompanying text.

106. There is a mechanism that the SEC has for stopping truly bad corporate behavior. It is delisting a corporation - in essence taking away their access to the markets for capital. However, during my almost five years at the SEC the Commission rarely took this action against a corporation for its bad acts. Why? Because we recognized that doing so would, cripple (if not debilitate) the corporation, theoretically impacting thousands of investors.

107. But BHR advocates may not be happy anyway. Infra, part four B.

108. See Nan Ellis \& Steven Dow, Attaching Criminal Liability to Credit Rating Agencies: Use of the Corporate Ethos Theory of Criminal Liability, 17 U. PA. J. Bus. L. 167, 173 (2009) (providing a summary of the difference between the goals of criminal and civil liability, " $t]$ he public policy objectives served by imposition of civil liability differ significantly from those of criminal law. Civil liability is largely compensatory - the judgments imposed serve to compensate injured plaintiffs. Criminal law is largely punitive - the fines and other sanctions imposed serve to punish criminal defendants. While both criminal and civil liabilities are intended to deter future misconduct, the similarities end there. Criminal law acts as a vehicle to punish wrongdoers, as a deterrent against future wrongdoing, and serves a rehabilitative function.”). 
note, "[i]n the case of corporate crime, retribution - one of the goals of criminal law - is achieved through assessment of a fine on the corporation" 109 Unfortunately, there is some indication that the use of fines to punish corporations seems to have failed in its deterrent effect. ${ }^{110}$ Prof. W. Robert Thomas takes a different approach to examining corporate criminal liability. Thomas argues that, instead of looking at corporate punishment primarily through the lens of criminal law, an examination of corporate jurisprudence is integral to our understanding of the issues that come into play when doling out features of corporate punishment under criminal law. ${ }^{11}$ According to Thomas, this stems from the fundamentally "diametrically opposed conceptions of what the corporation is." 112 On the one hand, criminal law treats the corporation as a single person. On the other hand, corporate law treats the corporation as "systems of designs" that can be tinkered with and used as needed. ${ }^{113}$ According to Thomas,

The fine, after all, is the paradigmatic form of corporate punishment; it is the first, and for decades the only, method by which the criminal law could hold a corporation criminally responsible for its misconduct. Today, it continues to be the most prevalent method of punishing corporations: nearly $90 \%$ of organizations convicted between 1999 and 2012 received some form of financial sanction. Moreover, at least at first glance, there is much to recommend about corporate-criminal fines. Comparatively speaking, fines are easy to administer; easy to scale in response to the size of the corporation, the severity of the crime, and a host of other factors; easy to predict in their consequences to third parties (including their social benefits); and easy to see as fitting punishmentwhat better way to punish an entity designed largely to create wealth than to seize from it its wealth? ${ }^{114}$

Nonetheless, Prof. Thomas argues that criminal fines are structurally incapable of satisfying the "standard goals of punishment." 115 Thomas also mentions a number of other interventions that have been taken more recently to punish corporations - namely, dissolution, corporate probation, regulatory intervention, and suspension. ${ }^{116}$ However, the structural issues persist. If TNCs cannot be held liable under international law then it must still rely on the domestic legal system. As such, any solution that is designed to hold TNCs accountable would have to work within that reality.

109. Id. at 173 .

110. W. Robert Thomas, The Ability and Responsibility of Corporate Law to Improve Criminal Fines, 78 Oніо ST. L.J. 601, 603 (2017) (arguing that, under U.S. law, the idea of holding corporations criminally liable has, in his words "roundly failed.").

111. Id. at 604 .

112. Id.

113. Id. at 604-05.

114. Id. at 605 (footnotes omitted).

115. Id. at 603 .

116. Id. at 603-04. 
To that end, there seems to be some acknowledgment that a holistic approach would be the best way to hold corporations accountable for egregious criminal behavior. For instance, in 2016, Amnesty International and the International Corporate Accountability Roundtable published a report proposing a multifaceted strategy for addressing the impunity gap between egregious corporate criminal behavior and the means to combat the criminal activity; the report (entitled The Corporate Crimes Principles or the Principles) is based on ten principles that the organizations urge governments' to use when pursuing, investigating and prosecuting corporate crimes. ${ }^{117}$ The Principles are comprehensive: they provide a fulsome discussion on the many issues and challenges that are faced in bringing egregious corporate behavior to justice, while taking steps to discuss solutions. One key facet of the Principles is its insistence that remedies for the victim be a part of the overall strategy employed by prosecutors. ${ }^{118}$ Therefore, it offers a robust program that is based on the reality that we currently live in - namely that there is no specific mechanism for holding TNCs liable under international law. ${ }^{119}$ As such, the Principles provide a robust counter point to consider in examining what mechanisms can be used to prosecute TNCs under international criminal law; lending itself in support of the notion that TNCs should be held liable for egregious acts.

$$
\text { B. . . or Maybe Not }
$$

Legend has it that, in $281 \mathrm{BC}$, King Pyrrhus of Epirus battled an advancing Roman army to ward off invasion and domination by the Romans against the Greeks. ${ }^{120}$ In the first two battles Pyrrhus and his army were victorious but the resulting toll taken on his troops was so heavy that Pyrrhus eventually lost the

117. The PrinciPLES, supra note 7, at 1, 9, 19, 28, 34, 42, 47, 53, 58, 64. Specifically, the ten principles are: (1) Fight impunity for corporate crimes by investigating and prosecuting offences; (2) Fight impunity for cross-border corporate crimes by choosing to assert jurisdiction; (3) Guarantee accountability and transparency in the justice process when pursuing corporate crimes; (4) Identify the legal standards and secure the evidence needed to establish liability for corporate crimes in your jurisdiction; (5) Collaborate widely to ensure accountability for corporate crimes, particularly in cross-border cases; (6) Pursue charges that reflect the gravity of the corporate crimes committed; (7) Investigate and prosecute those corporate actors most responsible for the wrongdoing; (8) Use all available legal tools to collect evidence, build cases and obtain the cooperation of critical witnesses in corporate crimes cases; (9) Ensure that victims of corporate crimes are able to obtain effective remedies; and (10) Put in place appropriate measures and incentives to protect victims, informants, whistle-blowers, witnesses and experts in corporate crimes cases. Id.

118. Id. at 58 .

119. For additional challenges relating to the use of the ICC to establish corporate liability, see Kaeb, supra note 40, at 381-91 (discussing issues such as the appropriate penalty to levy against a corporation)

120. N.S. Gill, Pyrrhic Victory, ThоughtCo., https://www.thoughtco.com/pyrrhic-victory120452 [https://perma.cc/786F-BGBK]. 
war. ${ }^{121}$ Specifically, the Roman army was so much larger than the king's that they could more easily absorb the losses of the specific battles, even though Rome's overall losses were so much greater than their opponents. ${ }^{122}$

One wonders whether the BHR movement might not be subjecting itself to the same Pyrrhic victory. The specific challenges are two-fold. First, just like with Pyrhhus, there is some concern that the movement might be spreading itself too thin. For instance, the BHR movement has, in many ways, made significant advancements since the BHR agenda began to take hold on the international scene. The issues that have mobilized scholars and practitioners have included everything from data privacy to human trafficking. The U.N.'s mandate for the Working Group on Business and Human Rights is a prime example of this. The mandate set forth requests that the Working Group promote good practices, to conduct country visits, make appropriate recommendations for access to remedies, develop a dialogue, and more. ${ }^{123}$ The question remains then whether the expansive mandate will lead to a diluted focus on the part of people who would like to advance the cause. ${ }^{124}$

Second, there is a concern that the cost of winning the war itself might be too high given the potential devastation that could be left in its wake. For instance, Walmart is the number one employer in the world. ${ }^{125}$ Millions of consumers rely on Walmart due to its relatively low-cost options for everyday household products and produce. ${ }^{126}$ What if there was a situation where Walmart was tried for crimes against humanity and lost? What would be the ripple effects throughout the economy? Part of the reason why the BHR agenda suffers is because there is often another battle that happens when corporations go into developing countries. ${ }^{127}$ On the one hand there are people in the community who

121. $I d$.

122. Id. Notice the parallels? One wonders if the same fate will befall human rights organizations and NGOs whose resources are traditionally dwarfed by their corporate adversaries.

123. This echoes the mandate of the Working Group's predecessor, UN Special Rapporteur John Ruggie. According to Prof. Ruggie, the scope of the issues was so vast and broad that it turned his original two-year term into an eight-year affair. Working Group on the issue of human rights and transnational corporations and other business enterprises, U.N. HuM. RTS. OFF. OF THE HIGH COMMISSIONER, https://www.ohchr.org/en/issues/business/pages/wghrandtransnationalcorporations andotherbusiness.aspx [https://perma.cc/HEC6-268W].

124. One wonders, for instance, if the reason why the ICC has still not brought a corporate executive to trial is an outgrowth of issues such as this.

125. Alexander E.M. Hess \& Robert Serenbetz, 15 biggest employers in the world, USA TODAY (Aug. 24, 2014), https://www.usatoday.com/story/money/business/2014/08/24/24-7-wall-stbiggest-employers/14443001/ [https://perma.cc/WFL8-QQ58].

126. This is particularly true in rural communities where the area Walmart is sometimes the only source of fresh produce. See Ed Pikington, What happened when Walmart left, THE GUARDIAN, https:/www.theguardian.com/us-news/2017/jul/09/what-happened-when-walmart-left [https://perma.cc/2ZTA-P7KQ].

127. See, e.g., Ariadna Tovar \& Marianne Betrand, Maxima Acuña: the story of how a business impacted human rights defenders in Dying To be Heard (forthcoming) (discussing the 
get upset because the company is doing very bad things. On the other hand, there are a significant number of people who would oppose the actions of the advocates because the corporation is bringing in jobs. This is at the heart of the fear of punishing corporations - because in the end they are legal fictions, they are not individuals and yet it's the flesh and blood employees and impacted communities that are often harmed. As a result, sometimes you can find yourself as an advocate getting everything you want and still losing. Why? Because the metaperson that is the TNC picks up and moves to another location.

\section{CONCLUSION}

As noted previously, TNCs are not in fact one single monolithic, but rather a series of subsidiaries and other legal entities that are organized under the laws of many different jurisdictions. The idea of examining the "IT" that makes up the TNC narrative then grows difficult you realize that the IT is really a series of its. On a basic, practical level this makes investigating the corporation a timeconsuming and expensive affair. This is multiplied further when one considers that each of these subsidiaries is located in a different jurisdiction with a different set of procedural rules and legal precedents (not to mention limitations on interjurisdictional cooperation).

As such, using the Principles to move towards greater TNC accountability may be the best approach. It allows prosecutors to work within the system that they have without taking the drastic step of trying to bring a TNC to justice ${ }^{128}$ under international law. It also allows investigators to work within the current state-centered model. ${ }^{129}$ However, we must acknowledge the cost. Specifically, our current system allows for TNCs to pick up and go anywhere it wants if it is unhappy with the outcome (something that may be less likely to happen when the TNC is prosecuted in an international venue). As such, it may be that the best solution would be better comity within the various state parties to achieve justice for these people while still allowing corporations to provide much needed development. Otherwise, a Pyrrhic victory will ensue.

story of Maxima Acuna, a human rights defender, who is vilified by members of her own community). See also Paul Krugman, Coal Country is a State of Mind, N.Y. TiMEs (Mar. 31, 2017), https://www.nytimes.com/2017/03/31/opinion/coal-country-is-a-state-of-mind.html [https://perma.cc/H94G-BFTV] (explaining why West Virginia, a state where coal is no longer the dominant industry, still focuses its interests and loyalties around it).

128. There is an irony to the position being made here: if corporations want the benefit of other laws, then they should be subject to criminal statutes.

129. Surya Deva, Human Rights Violations by Multinational Corporations and International Law: Where From Here?, 19 ConN. J. InT'L L. 1 (2003); Larry Cata Backer, The Emerging Normative Structures of Transnational Law: Non-State Enterprises in Polycentric Asymmetric Global Orders, 31 BYU J. PUB. L. 1 (2016). 